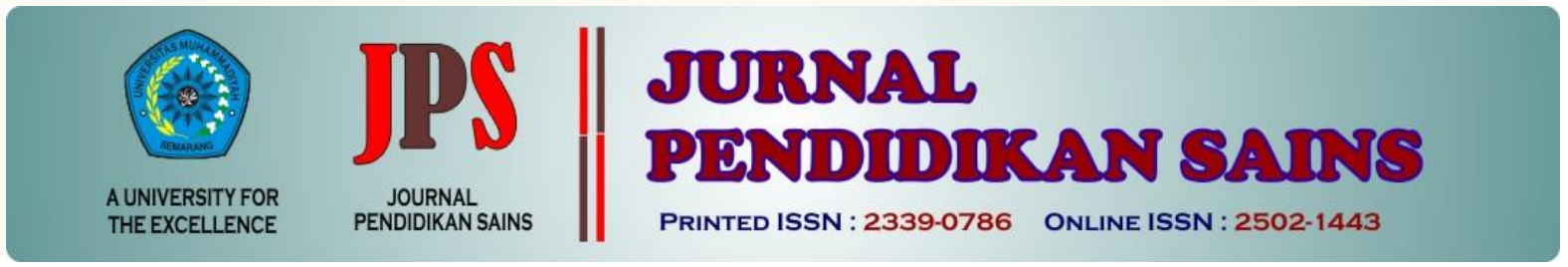

http://jurnal.unimus.ac.id/index.php/JPKIMIA

\title{
PENINGKATAN KETERAMPILAN BERPIKIR ANALISIS CALON GURU IPA MELALUI MODEL 4A (ANALISIS FENOMENA, ANALISIS INFORMASI, ANALISIS DATA, ANALISIS TEMUAN)
}

Oleh:

Septi Budi Sartika, Nur Efendi, Luluk Iffatur Rocmah

Fakultas Psikologi dan Ilmu Pendidikan, Universitas Muhammadiyah Sidoarjo

\begin{tabular}{ll}
\hline \multicolumn{2}{l}{ Article history } \\
\hline Submission & $: 2020-06-04$ \\
Revised & $: 2020-09-22$ \\
Accepted & $: 2020-09-26$
\end{tabular}

Keyword:

analytical thinking skills, 4A models, pre-service teacher's student of natural science education

\begin{abstract}
Analytical thinking skills are important in all areas of work, so they need to be trained in school. But in reality, only 5\% of Indonesian students have analytical competencies, competencies of most students at the level of knowledge or memorization. The purpose of the study describes the analytical thinking skills of pre-service teacher's student of natural science in applying the 4A model (phenomenon Analysis, information Analysis, data Analysis, and finding Analysis). The research method uses experimental research, with a sample of preservice teacher's student of natural science. Research instruments are activity observation sheets, analytical thinking skills tests, and response questionnaires. Data analysis techniques use quantitative descriptive. The results of the study obtained that there is an improvement in the analytical thinking skills of pre-service teacher's student by applying the $4 \mathrm{~A}$ model, this is supported by relevant activities in lectures and a positive response to the implementation of model 4A (Phenomenon Analysis, Information Analysis, Data Analysis, and Findings Analysis) in fluid lectures. These results, need to be scanned into other courses so that it is likely that analytical thinking skills will increase significantly.
\end{abstract}

\section{Pendahuluan}

Keterampilan berpikir analisis dibutuhkan di semua bidang, oleh sebab itu perlu dilatihkan di sekolah. Berpikir analisis merupakan kemampuan dasar yang harus dimiliki siswa yang merupakan bagian dari metode ilmiah. Anderson dan Krathwohl (2001: 79) menyatakan analisis merupakan kemampuan kognitif urutan keempat setelah pengetahuan, pemahaman, dan aplikasi. Aspek analisis terbagi ke dalam 3 (tiga) kategori, yaitu: 1) analisis bagian (unsur) seperti melakukan pemisahan fakta, pendefinisian unsur, argumen, aksioma (asumsi), dalil, hipotesis, dan kesimpulan; 2) analisis hubungan (relasi) seperti menghubungkan unsur-unsur dari suatu sistem (struktur); dan 3) analisis sistem seperti mampu mengenal unsur-unsur dan hubungannya dengan struktur yang terorganisasikan. Dalam melatihkan keterampilan berpikir analisis, siswa diajak untuk mampu berpikir secara langkah demi langkah sebelum menyimpulkan segala sesuatu yang diamatinya. Hal ini berarti siswa dilatih untuk tidak langsung menjustifikasi/

*Corresponding Author:

$\begin{array}{ll}\text { Nama } & \text { : Septi Budi Sartika } \\ \text { Lembaga } & \text { : Universitas Muhammadiyah Sidoarjo } \\ \text { Email } & : \text { septibudi1@ @umsida.ac.id }\end{array}$


menyimpulkan segala sesuatu jika belum dibuktikan dengan logika dan akal sehat. Dengan demikian dibutuhkan keterampilan berpikir analisis yang harus dilalui dengan baik sehingga kesimpulan akan sesuatu itu dapat dipertanggungjawabkan.

Pada kenyataannya, hanya $5 \%$ pelajar Indonesia memiliki kompetensi analisis, kompetensi sebagian besar pelajar pada tingkat pengetahuan atau hafalan. Hal tersebut berdasarkan laporan McKinsey Global Institute "Indonesia Today" dan sejumlah data rangkuman Kementerian Pendidikan dan Kebudayaan (Kemendikbud) tahun 2013. Kompetensi pelajar Indonesia masih di bawah pelajar lain di Asia, seperti Jepang, Thailand, Singapura, dan Malaysia (Edupost, 2012). Kemampuan anak Indonesia usia 15 tahun di bidang matematika, sains, dan membaca masih rendah dibandingkan dengan anak-anak lain di dunia, ini merupakan hasil tes Programme for International Student Assessment (PISA) 2012, di mana Indonesia berada di peringkat ke-64 dari 65 negara yang berpartisipasi (Harian Kompas Kamis, 5 Desember 2013). Hal yang sama tentang masih rendahnya kemampuan analisis juga terjadi di SMP. Hal ini dipertegas dengan studi pendahuluan bahwa keterampilan berpikir analisis siswa kelas VII di salah satu SMP Negeri di Sidoarjo masih rendah dan guru Ilmu Pengetahuan Alam (IPA) belum melatihkan keterampilan berpikir analisis secara khusus dalam mengajarkan IPA (Sartika, 2015).

Salah satu model pembelajaran yang mampu melatih dan meningkatkan keterampilan berpikir analisis adalah model 4A. Adanya peningkatan keterampilan berpikir analisis siswa SMP melalui model 4A (Analisis Fenomena, Analisis Informasi, Analisis Data, dan Analisis Temuan) yang signifikan (Sartika, 2019) menunjukkan bahwa model 4A mampu melatih siswa meningkatkan keterampilan berpikir analisis. Pembelajaran dengan model 4A juga efektif dalam meningkatkan keterampilan berpikir analisis. Model 4A sesuai namanya memiliki 4 sintaks, meliputi: 1) analisis fenomena, 2) analisis informasi, 3) analisis data, dan 4) analisis temuan.

Menurut Sartika (2019), analisis fenomena bertujuan menganalisis kejadian fenomena sehari-hari tentang konsep materi yang akan disampaikan sehingga siswa dapat merumuskan masalah, analisis informasi bertujuan untuk menganalisis informasi sehingga siswa dapat merumuskan hipotesis, analisis data bertujuan untuk menganalisis data melalui investigasi/ penyelidikan sehingga siswa dapat memperoleh temuan, analisis temuan bertujuan untuk menganalisis hasil temuan sehingga siswa dapat menyimpulkan.

Harapan peneliti adalah ada peningkatan keterampilan berpikir analisis calon guru IPA dengan menerapkan model 4A.

\section{Metode Penelitian}

Penelitian menggunakan desain penelitian eksperimen yaitu one group only posttest design (Fraenkel et al, 2011). Penelitian dilakukan pada Semester Genap Tahun Akademik 2019/2020. Populasi dan sampel adalah semua calon guru IPA yang memprogram mata kuliah Fluida, prodi Pendidikan IPA, Fakultas Psikologi dan Ilmu Pendidikan, Universitas Muhammadiyah Sidoarjo. Prosedur penelitian dimulai dari penyusunan perencanaan dan evaluasi perkuliahan, penyusunan perangkat dan instrumen penelitian. Pelaksanaan perkuliahan mengikuti Rencana Pembelajaran Semester (RPS). Perkuliahan terjadi melalui 2 cara yaitu tatap muka (sebelum pandemi covid-19) dan tatap maya (saat pandemi covid-19). Teknik pengumpulan data menggunakan angket dan tes. Teknik analisis data menggunakan deskriptif kuantitatif (Sugiyono, 2017).

\section{Hasil Penelitian dan Pembahasan}

Hasil penelitian dan pembahasan sebagai berikut:

1. Aktivitas Calon Guru IPA

Berikut disajikan tabel aktivitas calon guru IPA selama pembelajaran fluida:

Tabel 1. Aktivitas Calon Guru IPA

\begin{tabular}{|c|c|c|c|c|c|c|}
\hline \multirow[b]{2}{*}{ No } & \multirow{2}{*}{$\begin{array}{l}\text { Aktivitas } \\
\text { Calon guru } \\
\text { IPA }\end{array}$} & \multicolumn{5}{|c|}{ Persentase $(\%)$} \\
\hline & & SB & B & $\mathrm{CB}$ & $\mathrm{KB}$ & TB \\
\hline 1 & $\begin{array}{l}\text { Memahami } \\
\text { Capaian } \\
\text { Pembelajaran } \\
\text { Mata Kuliah }\end{array}$ & 48,0 & 35,3 & 17,7 & 0 & 0 \\
\hline 2 & $\begin{array}{l}\text { Menganalisis } \\
\text { fenomena } \\
\text { untuk } \\
\text { merumuskan } \\
\text { masalah }\end{array}$ & 11,8 & 58,8 & 26,5 & 2,9 & 0 \\
\hline 3 & $\begin{array}{l}\text { Menganalisis } \\
\text { informasi } \\
\text { untuk } \\
\text { merumuskan } \\
\text { hipotesis }\end{array}$ & 17,6 & 52,9 & 23,5 & 5,9 & 0 \\
\hline
\end{tabular}




\begin{tabular}{|c|c|c|c|c|c|c|}
\hline No & Aktivitas & \multicolumn{5}{|c|}{ Persentase $(\%)$} \\
\hline 4 & $\begin{array}{l}\text { Menganalisis } \\
\text { data melalui } \\
\text { percobaan } \\
\text { untuk } \\
\text { memperoleh } \\
\text { temuan }\end{array}$ & 19,7 & 50,2 & 27,2 & 2,9 & 0 \\
\hline 5 & $\begin{array}{l}\text { Menganalisis } \\
\text { temuan untuk } \\
\text { membuat } \\
\text { kesimpulan }\end{array}$ & 15,8 & 52,7 & 23,7 & 7,9 & 0 \\
\hline 6 & $\begin{array}{l}\text { Calon guru } \\
\text { IPA } \\
\text { melakukan } \\
\text { kegiatan } \\
\text { relevan }\end{array}$ & 7,9 & 28,9 & 36,8 & 18,4 & 7,9 \\
\hline
\end{tabular}

Keterangan:

$\mathrm{SB}=$ Sangat Baik; $\mathrm{B}=$ Baik; $\mathrm{CB}=$ Cukup Baik;

$\mathrm{KB}=$ Kurang Baik; $\mathrm{TB}=$ Tidak Baik

Berdasarkan Tabel 1, diperoleh bahwa aktivitas siswa dikatakan relevan dengan kategori sangat baik, baik, dan cukup baik. Menurut Yamin (2007), aktivitas belajar dapat terindikasikan pada saat siswa belajar secara aktif. Dengan memperhatikan Tabel 1, maka dapat dikatakan bahwa aktivitas calon guru IPA masih relevan dengan pembelajaran karena sebagian besar berada pada kriteria sangat baik, baik, dan cukup baik. Perlu digaris bawahi bahwa ada aktivitas calon guru IPA yang kurang relevan yaitu pada kriteria kurang baik dan tidak baik.

Prinsip belajar ialah kegiatan untuk mengubah tingkah laku melalui perbuatan. Ada atau tidaknya belajar diindikasikan oleh ada atau tidaknya aktivitas. Aktivitas belajar merupakan interaksi kegiatan belajar-mengajar, meliputi aktivitas guru dan siswa (Sardiman, 2011). Menurut Djamarah (2010), penggunaan metode, pendekatan belajar mengajar dan orientasi belajar menyebabkan aktivitas belajar setiap individu berbeda-beda. Perbedaan aktivitas belajar ini akan melahirkan level aktivitas belajar yang tidak relevan sampai dengan relevan sesuai dengan metode, pendekatan pembelajaran yang diterapkan oleh guru.

Menurut Wulandari et al (2018), aktivitas siswa dalam pembelajaran dengan mengembangkan keterampilan berpikir analisis meliputi: proses pencocokan kognitif, proses kognitif membuat klasifikasi, proses kognitif menganalisis kesalahan, proses kognitif menggeneralisasi, dan proses kognitif mengindentifikasi. Proses kognitif tersebut ada pada aktivitas nomor 2, 3, 4, dan 5 pada Tabel
1. Dengan demikian keterampilan berpikir analisis merupakan keterampilan yang penting untuk mahasiswa calon guru (Areesophonpichet, 2013). Hal ini juga sejalan dengan hasil penelitian Gunada, dkk (2017) bahwa pembelajaran berbasis masalah dapat meningkatkan aktivitas mahasiswa.

\section{Keterampilan Berpikir Analisis Calon Guru IPA}

Indikator keterampilan berpikir analisis yang diukur meliputi: membedakan, mengorganisasikan, dan mengatribusi. Konsep Fluida yang disampaikan meliputi fluida statis dan fluida dinamis serta aplikasinya dalam kehidupan sehari-hari.

Hasil keterampilan berpikir analisis calon guru IPA sebagai berikut:

Tabel 2. Sebaran Keterampilan Berpikir Analisis Calon Guru IPA

\begin{tabular}{lcc}
\multirow{2}{*}{\multicolumn{1}{c}{ Indikator }} & \multicolumn{2}{c}{ Nilai Rata-rata } \\
\cline { 2 - 3 } & Pre-test & Post-test \\
\hline Membedakan & 23,27 & 32,7 \\
\hline Mengorganisasikan & 8,95 & 28,2 \\
\hline Mengatribusi & 19,47 & 18,0 \\
\hline \multicolumn{1}{c}{ Jumlah Nilai Rerata } & 51,68 & 78,9 \\
\hline
\end{tabular}

Berdasarkan Tabel 2, jumlah nilai ratarata keterampilan berpikir analisis dapat dikatakan mengalami peningkatan dengan kategori tinggi yaitu 78,9 dari 51,68 dengan rerata indikator mengatribusi paling rendah di antara indikator yang lainnya dan justru malah turun di nilai post-test nya. Hal ini disebabkan karena mengatribusi adalah kemampuan memberi label terhadap sesuatu, label diberikan jika seseorang mampu memahami fenomena dan informasi yang akurat dan relevan. Menurut Anderson dan Krathwohl (2001), mengatribusi adalah menerapkan pandangan, bias, nilai/ maksud, menemukan makna yang tersirat. Dengan demikian apabila seseorang tidak memiliki pengalaman sebelumnya terhadap suatu peristiwa maka akan sulit untuk memberi label.

Menurut Nugroho (2017), keterampilan berpikir analisis (C4) merupakan salah satu dari hasil belajar kognitif. Untuk memperoleh hasil belajar kognitif yang tinggi, maka perlu mengembangkan keterampilan berpikir analisis.Keterampilan berpikir analisis merupakan keterampilan berpikir tingkat tinggi (Sartono dkk, 2017).

Menurut Suryanda dkk (2016), model pembelajaran yang tepat untuk mengembangkan kemampuan berpikir analisis 
yaitu model pembelajaran yang dapat mendorong seseorang dalam proses penyelesaian masalah. Model 4A merupakan model pembelajaran dimulai dari permasalahan, penelusuran pustaka, penyeledikan, penyelesaian masalah. Hal ini terdapat dilihat dari sintaks model 4A, yaitu menganalisis fenomena untuk merumuskan masalah, menganalisis informasi untuk merumuskan hipotesis, menganalisis data untuk memperoleh temuan, dan menganalisis temua untuk menyimpulkan sekaligus penyelesaian masalah.

\section{Respons Calon Guru IPA}

Adapun hasil respons calon guru IPA sebagai berikut:

Tabel 3. Respons Calon Guru IPA

\begin{tabular}{|c|c|c|}
\hline \multirow[t]{2}{*}{ Respons Mahasiswa } & \multicolumn{2}{|c|}{$\begin{array}{c}\text { Persentase } \\
(\%) \\
\end{array}$} \\
\hline & $(+)$ & $(-)$ \\
\hline $\begin{array}{l}\text { Adanya Rencana } \\
\text { Pembelajaran Semester } \\
\text { (RPS) yang ditunjukkan ke } \\
\text { mahasiswa. }\end{array}$ & 94,7 & 5,3 \\
\hline $\begin{array}{l}\text { Adanya modul praktikum } \\
\text { fluida. }\end{array}$ & 94,7 & 5,3 \\
\hline $\begin{array}{l}\text { Adanya bahan ajar baik } \\
\text { berupa ppt, pdf, atau video. }\end{array}$ & 100 & 0 \\
\hline $\begin{array}{l}\text { Perangkat pembelajaran } \\
\text { yang digunakan baru. }\end{array}$ & 78,9 & 21,1 \\
\hline $\begin{array}{l}\text { Perangkat pembelajaran } \\
\text { yang digunakan mudah. }\end{array}$ & 63,2 & 36,8 \\
\hline $\begin{array}{l}\text { Model pembelajaran 4A } \\
\text { (Analisis Fenomena, } \\
\text { Analisis Informasi, Analisis } \\
\text { Data, dan Analisis Temuan) } \\
\text { tergolong baru. }\end{array}$ & 94,7 & 5,3 \\
\hline $\begin{array}{l}\text { Model pembelajaran 4A } \\
\text { (Analisis Fenomena, } \\
\text { Analisis Informasi, Analisis } \\
\text { Data, dan Analisis Temuan) } \\
\text { itu menyenangkan. }\end{array}$ & 84,2 & 15,8 \\
\hline $\begin{array}{l}\text { Mahasiswa mengetahui } \\
\text { tentang keterampilan } \\
\text { berpikir analis. }\end{array}$ & 84,2 & 15,8 \\
\hline $\begin{array}{l}\text { Mahasiswa menyadari } \\
\text { bahwa keterampilan berpikir } \\
\text { analisis menjadi meningkat. }\end{array}$ & 94,7 & 5,3 \\
\hline $\begin{array}{l}\text { Mahasiswa mengetahui } \\
\text { tentang kemampuan } \\
\text { menyelesaikan masalah. }\end{array}$ & 78,9 & 21,1 \\
\hline $\begin{array}{l}\text { Mahasiswa memahami } \\
\text { proses penyelesaian } \\
\text { masalah. }\end{array}$ & 84,2 & 15,8 \\
\hline $\begin{array}{l}\text { Dosen memberikan kontrak } \\
\text { perkulihan. }\end{array}$ & 100 & 0 \\
\hline $\begin{array}{l}\text { Dosen aktif dalam } \\
\text { membimbing perkuliahan. }\end{array}$ & 94,7 & 5,3 \\
\hline Mahasiswa hadir dalam & 68,4 & 31,6 \\
\hline
\end{tabular}

\begin{tabular}{lcc}
\multicolumn{1}{c}{ Respons Mahasiswa } & \multicolumn{2}{c}{$\begin{array}{c}\text { Persentase } \\
(\%)\end{array}$} \\
\cline { 2 - 3 } & $(+)$ & $(-)$ \\
\hline perkuliahan. & & \\
\hline $\begin{array}{l}\text { Mahasiswa aktif dalam } \\
\text { forum diskusi. }\end{array}$ & 73,7 & 26,3 \\
\hline $\begin{array}{l}\text { Mahasiswa semakin percaya } \\
\text { diri dalam perkuliahan. }\end{array}$ & 79,0 & 21,0 \\
\hline $\begin{array}{l}\text { Mahasiswa mampu } \\
\text { berkomunikasi dengan baik. }\end{array}$ & 78,9 & 21,1 \\
\hline
\end{tabular}

Berdasarkan Tabel 3, diperoleh bahwa mahasiswa calon guru IPA merespons positif perkuliahan fluida. Respons positif ini ditandai dengan persentase respons positif di atas 63\%. Menurut Harvey (2006), respon merupakan bentuk kesiapan dalam menentukan sikap yang baik dalam bentuk positif dan negatif terhadap objek dan situasi. Objek yang dimaksud adalah model pembelajaran 4 A dengan 4 sintaks dan situasi dalam perkuliahan Fluida. Dengan memperhatikan data persentase respon calon guru IPA yang cukup positif berarti telah menentukan sikap yang baik serta mampu mempersiapkannya dalam perkuliahan Fluida dengan model pembelajaran 4A. Berdasarkan Tabel 3, respons calon guru IPA terhadap perkuliahan Fluida dengan model pembelajaran 4A dikategorikan positif. Respon dikatakan sangat positif jika 76$100 \%$ (Arikunto, 2010).

Menurut Poerwadarminta (2003), respon berarti reaksi atau tanggapan berupa penerimaan, penolakan, atau sikap acuh tak acuh terhadap apa yang disampaikan oleh komunikator dalam pesannya. Respons mahasiswa calon guru ini dikatakan sangat positif. Hal ini karena pembelajaran fluida yang telah dilakukan lain dari biasanya. Misalnya pada perangkat pembelajaran yang digunakan, model pembelajaran yang diterapkan, adanya fenomena permasalahan yang update, adanya langkah-langkah berpikir analisis dalam penyelesaian masalah dosen aktif dalam perkuliahan, dan mahasiswa menjadi percaya diri. Menurut Salam, dkk (2017), minat dan motivasi yang tinggi akan berdampak pada hasil belajar mahasiswa. Dengan demikian dapat dikatakan bahwa respons yang positif berdampak pada nilai keterampilan berpikir analisis calon guru IPA. 


\section{Simpulan dan Saran \\ Simpulan}

Berdasarkan hasil penelitian dan pemabahasan dapat disimpulkan bahwa ada peningkatan keterampilan berpikir analisis calon guru IPA dengan menerapkan model 4A, hal ini didukung oleh aktivitas yang relevan dalam perkuliahan dan respons yang positif terhadap penerapan model 4A (Analisis Fenomena, Analisis Informasi, Analisis Data, dan Analisis Temuan) pada perkuliahan Fluida.

Saran sebagai berikut:

Rekomendasi penelitian selanjutnya

1. Dosen sebaiknya menyediakan waktu yang disepakati untuk melakukan diskusi online, sehingga kuliah online tidak mengurangi makna seperti kuliah tatap muka.

2. Dosen sebaiknya menyediakan tutorial kegiatan praktikum jika alat dan bahan adalah bahan-bahan yang mudah ditemukan dalam kehidupan sehari-hari, sehingga kegiatan praktikum tidak mengulang karena data kurang tepat.

3. Dosen sebaiknya memberikan penjelasan materi secara langsung melalui video conference dengan mengundang seluruh anggota kelas yang memprogram fluida, sehingga mahasiswa mampu memahami materi layaknya kuliah tatap muka.

\section{Ucapan Terima Kasih}

Terimakasih disampaikan kepada seluruh tim Riset Terapan Institusi (RTI) dan Direktorat Riset dan Pengabdian kepada Masyarakat (DRPM) Universitas Muhammadiyah Sidoarjo melalui supportnya dalam menyelesaikan penelitian ini.

\section{Daftar Pustaka}

Anderson dan Krathwol. (2001). A Revision Bloom's Taxonomy of Educational Objectives. New York: Addison Wesley Longman, Inc.

Areesophonpichet, Sornatte. (2013). A development of Analytical Thinking Skills of Graduate Students by Using Concept Mapping. The International Academic Forum dapat diunduh di www.iafor.org.
Arikunto, S. (2010). Prosedur Penelitian Suatu Pendekatan Praktik. 2010. Jakarta: PT. Rineka Cipta.

Djamarah, S. B. Psikologi Belajar, (2011). Jakarta: PT Rineka Cipta.

Edupost. (2012). Pelajar Indonesia Lemah Berpikir Analitisnya, Ganti Kurikulum Bukan Solusinya?. http://www.edupostjogja.com/edupo st-jogja/berita-nasional/pelajarindonesia-lemah-berpikir-analitisganti-kurikulum-bukan-solusinya diakses tanggal 26 Januari 2015.

Fraenkel, J. R., Wallen, N. E., \& Hyun, H. H.(2012). How to Design and Evaluate Research in education.

Gunada, I. W., Sahidu, H., \& Sutrio, S. (2017). Pengembangan Perangkat Pembelajaran Fisika Berbasis Masalah Untuk Meningkatkan Hasil Belajar dan Sikap Ilmiah mahasiswa. Jurnal Pendidikan Fisika dan Teknologi, 1(1), 38-46.

Harvey, V. S. (2006). Variables affecting the clarity of psychological reports. Journal of Clinical Psychology, 62(1), 5-18.

Kemendikbud. (2012). Implementasi Kurikulum $2013 . \quad$ Diakses dari https://www.kemdikbud.go.id/kemdikbud/ dokumen/Paparan/Paparan\%20Mendikbud \%20pada\%20Workshop\%20Pers.pdf diakses 26 Januari 2015.

Kompas. Edisi Kamis, 5 Desember 2013. Diakses dari https://lldikti12.ristekdikti.go.id/2013/12/0 5/skor-pisa-posisi-indonesia-nyaris-jadijuru-kunci.html dikases 26 Januari 2015.

Nugroho, A. (2017). The Implementation of Collaborative-Based Guided Discovery Reviewed From Students' Analytical Thinking Skills and Social Skills. Jurnal Inovasi Pendidikan IPA, 3(2), 128136.

Poerwadarminta, W. J. S. (2002). Kamus Umum Bahasa Indonesia, Balai Pustaka, Jakarta. 
Salam, A., Prabowo, P., \& Supardi, Z. I. (2017). Pengembangan Perangkat Perkuliahan Inovatif Berdasarkan Tingkat Otonomi Pebelajar pada Perkuliahan Fisika Dasar. JPPS (Jurnal Penelitian Pendidikan Sains), 4(2), 547-556.

Sardiman, A.M. (2011). Interaksi dan Motivasi Belajar Mengajar. Jakarta: Raja Grafindo Persada.

Sartono, N., Rusdi, R., \& Handayani, R. (2017). Pengaruh Pembelajaran Process Oriented Guided Inquiry Learning (POGIL) dan Discovery Learning terhadap Kemampuan Berpikir Analisis Siswa SMAN 27 Jakarta pada Materi Sistem Imun. Biosfer: Jurnal Pendidikan Biologi, 10(1), 58-64.

Sartika, Septi Budi. (2015). Keterampilan Berpikir Analitik Siswa SMP dalam Menyelesaikan Masalah IPA Berbasis Kurikulum 2013. Surabaya: Proceeding Seminar Nasional Pendidikan Sains 24 Januari 2015 di UNESA. ISBN: 978-60272071-0-3.

Sartika, Septi Budi. (2019). Model Pembelajaran 4A (Analisis Fenomena, Analisis Informasi, Analisis Data, Analisis Temuan) Untuk Meningkatkan Keterampilan Berpikir Analisis Siswa SMP dalam Mata Pelajaran IPA. Disertasi. Surabaya: Perpustakaan Pascasarjana UNESA.

Sugiyono, D. R. (2009). Metodologi Penelitian Pendidikan. Bandung: Alfabeta.

Suryanda, A., Azrai, E. P., \& Wari, N. (2016). Pengaruh Penerapan Model Pembelajaran Group Investigation (GI) terhadap Kemampuan Berpikir Analisis Siswa pada Materi Pencemaran Lingkungan. Biosfer: Jurnal Pendidikan Biologi, 9(2), 37-44.

Wulandari, I. G. A., Sa'dijah, C., As'ari, A. R., \& Rahardjo, S. (2018, June). Modified guided discovery model: A Conceptual Framework For Designing Learning Model Using Guided Discovery To Promote Student's Analytical Thinking
Skills. In Journal of Physics: Conference Series (Vol. 1028, No. 1, p. 012153). IOP Publishing.

Yamin, M. (2007). Kiat Membelajarkan Siswa. Jakarta: Gaung Persada Press. 